\title{
Defying the Global: The Cultural Connotations of "Islam" in Malaysia
}

\author{
SITI ZUBAIDAH MOHD HASHIM \\ "HAJAR ABDUL RAHIM \\ School of Humanities, Universiti Sains Malaysia, \\ 11800 USM Pulau Pinang, Malaysia \\ *Corresponding author: hajar@usm.my
}

Published online: 30 December 2016

To cite this article: Siti Zubaidah Mohd Hashim and Hajar Abdul Rahim. 2016. Defying the global: The cultural connotations of "Islam" in Malaysia. KEMANUSIAAN the Asian Journal of Humanities 23(Supp. 2): 81-98, https://doi.org/10.21315/kajh2016.23.s2.5

To link to this article: https://doi.org/10.21315/kajh2016.23.s2.5

\begin{abstract}
The cultural connotations of the word "Islam" is analysed in this study using a corpus-based semantic prosody analysis of Malaysian newspaper reports in English and Malay. Approximately 1.6 million words of Malaysian newspaper reports published between year 2014 and 2015 were used to develop two comparable sub-corpora of English and Malay data. The downward collocations (words with semantic content, i.e. nouns, verbs and adjectives) of the word "Islam" in the two sub-corpora formed the data for analysis and Partington's (2004) categorisation of semantic prosodies, i.e. positive, negative or neutral was employed in determining its prosody. The collocational patterns of "Islam" that emerged in the corpus of study suggest that the word has mostly positive and neutral prosodies in Malaysian newspapers. The cultural connotations of "Islam" that emerged from the analysis of the Malay corpus reflect the familiarity of Islam and its inherent link with the Malay language and culture, evident from the use and naturalisation of Arabic words pertaining to Islam in the Malay language. In the English corpus, the cultural connotations of "Islam" suggest its institutionalisation in the country's education system, banking system and financial establishments. These cultural connotations are in contrast with the generally negative representation of Islam in the Western and global discourse.
\end{abstract}

Keywords and phrases: Islam, cultural connotation, semantic prosody, Malaysia, Malay 


\section{Introduction}

Islam is a monotheistic religion and one of the major religions of the word. The total number of adherents of Islam in 2015 was approximately 1.7 billion people and it is the second largest religion in the world after Christianity (Johnson et al. 2015). As with other major religions, "Islam is being rocked and battered by the revolutionary changes of today's world" (Payne and Nassar 2003, 31). However, as pointed out by Kisaichi (2006), it would seem that the challenges faced by Muslims are far greater in many ways and the problems have worsened over the last decade following the September 11th incident. Since then "a general understanding appears to have arisen among people that the challenges posed by Islam now acquired human and global dimensions" and unfortunately, this phenomenon has earned Islam a certain reputation, such that every terrorist attack or a problem within and also outside the Muslim world has been "analysed in conjunction with the Islamic religion" (Kisaichi 2006, x). The global trend that has emerged with regard to Islam and Muslims suggests that both are perceived negatively in many parts of the world and there is an inclination to view the problems that arise "from a dualistic standpoint, namely as tussles between the Western (democratic) world and the world of Islam" (Kisaichi 2006, x).

This global phenomenon has spurred much interest in Islam and Muslims among researchers from various fields of enquiry. In the last decade, a number of linguistic studies have been carried out on Islam and words associated with it such as "Islamic" and "Muslim" to understand how the religion is portrayed and represented, especially in the West. Studies by Baker, Gabrielatos and McEnery (2012), Baker (2012; 2010) and Malcolm, Bairner and Curry (2010) for instance found that Islam is negatively represented in the media in the United Kingdom. The studies reveal that Islam and Muslims are portrayed as hostile, violent and in perpetual dispute with non-Muslims. Islam is also often represented as being extreme rather than moderate. The negative representation of Islam is also common in other Muslim-minority localities such as the US, particularly after the unfortunate September 11 incident. The studies that were carried out found that Muslims are often represented as fundamentalists, militants and terrorists (Jackson 2010; Laird, de Marrais and Barnes 2007; Martin and Phelan 2002). Studies done in other countries such as the Netherlands (d'Haenens and Bink 2006), Switzerland (Dahinden et al., 2011) and Australia (Kabir 2007) also reveal the same negative portrayal of Islam and Muslims in their media.

The poor representation of Islam in Muslim-minority communities especially in the West obviously is not generalisable, especially to Muslim majority countries. The assumption is that the negative representations or portrayal of Islam in nonMuslim majority countries may not arise in Muslim-majority nations as the personal and communal association Islam has with the people will not likely 
conjure up negative connotations. This is possibly the case in Malaysia as well where Islam is the official religion of the country and is an integral part of the society. Yet there has been no study to confirm this assumption. Studies on Islam in Malaysia in the last decade or so have focused mainly on local issues and three that have been commonly discussed are the relationship between Malays and Islam (e.g. Aini Maznina A. Manaf and Nerawi Sedu 2015; Norshahril Saat 2011), the political motive and the downfall of Islam Hadhari (e.g. Ahmad Fauzi Ahmad Hamid and Muhammad Takiyuddin Ismail 2014; Mohd Azizuddin Mohd Sani et al. 2009) and the debate on the use of "Allah" as restricted only to Muslims (e.g. Neo 2014; Sankar 2013).

The gap in the literature on the portrayal of Islam in Muslim majority contexts is the motivation for the current study on "Islam" in Malaysia, where Islam looms large as the country's official religion and where Muslims form a major segment of its multi-ethnic and multi-religious society. Malaysians practice different cultures and, most notably, are multilingual. "Malay is the most common language among Malaysians but the country, in fact, has a diverse linguistic panorama of speech communities" (Hajar and Shakila 2014, 11-12). ${ }^{1}$ While the Malay language is widely used by Malaysians, it is essentially the language of the Malays. The connection between the Malays and the Malay language is inextricable and institutionalised in Malaysia. The interpretation of what it means to be Malay in Malaysia, found in Article 160 of the Federal Institution of Malaysia, states that a Malay individual is a Muslim who speaks Malay and practices the Malay customs. This means that besides the Malay language, Islam is very much part of the Malay culture in Malaysia. In her discussion of "Malayness" in Malaysia, Maznah Mohamad (2011) addresses one of the frequently raised issues surrounding it, i.e. the Malays and Islam. She points out that the religion of Islam is more associated with Malays than any other ethnic groups in the country. This, she states, is part of the Malay identity or Malayness.

While Malay is prominent in Malaysia in terms of its functions and use as the official language of the country and as a lingua franca, English also has a place in the Malaysian linguistic context. Brought into the country by the British who colonised Malaya, English was the language of administration, the medium of instruction as well as the language of commerce and naturally English was transplanted into the local linguistic scenery. English was initially rejected by the Malays as it was the language taught by Christian missionaries during the British colonial rule (Asmah 1992; Yegar 1979). However today, as in many postcolonial nations, English is taught in schools and widely used as a second language in the country. 
Given the significance of Islam in Malaysia and its inherent connection with the Malay society, it is interesting to examine its cultural connotations in the Malay language in contrast to the English language in contemporary Malaysia. The cultural connotations of a word, that is, the typical connotations a word possesses in the community in which it is used, can influence its reputation. This form of connotation is analysable from the discourse pattern, that is, the repeated words and phrases with which a word is commonly found in a speech community (Stubbs 1996). The meaning of a word, as well as its reputation, is therefore influenced by the dominant cultural connotation which is repeatedly expressed in a discourse community. As this is often a reflection of the social reality of the speech community, recurrent wordings are "empirical evidence of how culture is encoded in lexis" (Hajar 2005, 83). Thus, in the current study, the pattern of words co-occurring with "Islam" forms the basis for the analysis of its cultural connotations in contemporary Malaysia. The study employed a computerised corpus-based analysis of the word "Islam" in English and in Malay in news texts published in local dailies to investigate the connotations that are conjured up in its usage and attempts to link the findings to the local and global realities of Islam.

\section{Semantic Prosody and Cultural Connotations}

The idea of semantic prosody was first proposed by John Sinclair in 1987 to provide empirical evidence of semantic meaning. According to Stubbs (2009), Sinclair's initial concept of semantic prosody provides a subjective description of meaning. This refers to the extended meanings of words that can be analysed by their semantic prosodies. The "extended meanings" of a word that semantic prosody denotes is the meaning distribution across word clusters and not limited to a single word (Stubbs 1995a). Although it is not explicitly evident in the descriptions of semantic prosody, the implication is that semantic prosody studies the attitude of a word according to its surroundings, that is, its collocates (Hunston 2007).

The methodology involves a corpus-assisted study of the communicative functions of linguistic units, typically at the lexical level. As a semantic prosody analysis is corpus-based, collocates of the expression under study can be identified automatically via computerised corpus linguistics tools. Corpus techniques such as frequency count provide statistical data that can be directly observed with the aid of computer tools. However, the collocation analysis based on concordance lines can only be done intuitively. Therefore, the study of semantic prosody employs both quantitative and qualitative analyses (Stubbs 2009). 
The literature suggests that the semantic prosody of an expression can be categorised as either favourable/positive, unfavourable/negative or neutral. Past studies show that there are several methodologies that can be employed to reveal the semantic prosody of a word. Among them, the methodology employed by Louw (1993; 2000), Sinclair (1991; 1998), Stubbs (1995a; 1995b; 1996) is the most similar. They employed the phraseological approach to semantic prosody which involves the analysis of the collocations of the word under study. A corpus-based analysis of the semantic prosody of a word would therefore be an analysis of its collocates. The following table presents the findings of the studies by Louw, Sinclair and Stubbs to illustrate the different categorisations of semantic prosody.

Table 1. Semantic prosody studies using the phraseological approach

\begin{tabular}{lll}
\hline Negative prosody & Positive prosody & Study \\
\hline $\begin{array}{l}\text { bent on, build up (of), end up, } \\
\text { symptomatic of }\end{array}$ & build up (a) & Louw $(1993 ; 2000)$ \\
break out, happen, set in & - & Sinclair $(1991 ; 1998)$ \\
accost, cause, signs & provide, career & Stubbs $(1995 \mathrm{a} ; 1995 \mathrm{~b} ; 1996)$ \\
\hline
\end{tabular}

Following the development in the study of semantic prosody, more research in English as well as in other languages has emerged. In his study on the semantic prosody of "telly" and "television", Rundell (2000) examined the semantic preference of the collocates of the two words. Semantic preference essentially organises words into particular semantic fields (McEnery and Hardie 2012). He found that the collocates of the node words include "sprawled", "plonked", "curled up" and "vegetate". These verbs can be categorised into a semantic class that indicates "laziness". Rundell therefore concluded that the words "telly" and "television" have a negative prosody.

Another study that employed a similar methodology as the one used by Louw, Sinclair and Stubbs is Begagić's (2013) analysis of the semantic prosody of the expression "make sense". Based on an analysis of different registers, i.e. newspapers and academic discourse, her study found that "make sense" is "more frequently found in a negative environment in the newspaper register than in the academic one" (Begagic 2013, 411). Interestingly, she also found that the semantic prosody of the expression changes when the property of the verb "make" is altered. This is evident from the expressions "make sense" and "making sense" which tend to appear in negative environments in contrast to "makes sense" and "made sense" which seem to occur in positive environments. Begagić therefore argues that "it cannot be stated that the collocation "make sense" has an overall negative prosody" (Begagić 2013, 411). 
A study on the semantic prosody of two Malay words perempuan (equivalent to "female") and wanita (equivalent to "woman/women") based on newspaper texts by Hajar (2005) involved the examination of the downward collocates of the two words. In terms of inherent senses, both words possess the features [+female] and [+human]. However, an analysis of their frequent collocates shows that the two words do not share the same semantic prosody. Wanita which also possesses the feature [+adult] generally has a positive prosody, while perempuan tends to have a negative prosody.

Another study on Malay is an analysis of the semantic prosody of the word setia which means "loyal" (Hishamudin and Norsimah 2012). Based on newspaper, book and magazine corpora, the study found that the linguistic value of the word is one of amelioration. This is contrary to earlier sociological and anthropological studies of setia which found the word to be aligned with negative values because instilling loyalty gives rise to "feudalism among Malaysians" (Hishamudin and Norsimah 2012, 359).

The above studies show that semantic prosody does not only indicate the extended meaning of a node word, but also how a word is being used in a particular context. According to Stubbs (1995a, 383), cultural connotations are "categories [that] remain implicit in the pervasive repetition of phrases and collocations". The analysis of cultural connotation is especially useful in understanding how a word is used in a specific culture or region. The study on the two Malay words wanita and perempuan for instance, shows that the different semantic prosodies reflect the cultural connotations of the words in Malay. The study found that wanita is a more formal representation of the female human, while perempuan commonly functions as a gender marker. Yet the recurring words and phrases or the discourse patterns of each one conjure up different prosodies which reflect the cultural connotations that are encoded in each word. Interestingly, this is not the case in Indonesia where perempuan seems to have a high status and used in important social contexts while wanita is considered a more general term (Hajar 2005).

Xiao and McEnery (2006) suggest that semantic prosody is able to compare meanings of words in more than one language. They point out that synonyms may have a sort of sameness in definition but this is not enough to completely represent one word with another, especially in terms of the pragmatics of the word in different languages. This point brings the discussion to the interest of the study in examining the cultural connotations of the word "Islam" in contemporary Malay and English in Malaysia. The analysis of its occurrence and semantic prosody in the two language will help us gain a better understanding of its 
cultural connotations in a non-Western, Muslim-majority, multilingual and multireligious context.

\section{Methodology}

A bilingual corpus comprising Malay and English language data was developed for the analysis of "Islam" in contemporary Malay and English in Malaysia. Newspaper reports published between 2014 and 2015 in the Berita Harian, a local Malay daily, and in The New Straits Times, a local English daily, formed the Malaysian Malay Newspaper sub-corpus (henceforth MMN sub-corpus) and the Malaysian English Newspaper sub-corpus (henceforth MEN sub-corpus) respectively. These two Malaysian dailies are mainstream newspapers published by the same news agency, namely The New Straits Times Press (M) Bhd. They were chosen for the study to ensure the comparability of the language data in Malay and in English. The bilingual corpus in total comprised 1.6 million words with approximately 830,000 words in each sub-corpus. To achieve the objectives of the study, two corpus techniques were used, i.e. frequency count and collocational analysis.

With the aid of the AntConc 3.4.3m linguistic analysis tool (Anthony 2015), the frequency count for the word "Islam" were generated from the two sub-corpora. In the Malay language, "Islam" functions as a noun and a verb but in English it occurs only as a noun. As this significant difference may skew the results of the study, it was decided that the adjectival form of "Islam" in English, i.e. "Islamic", is also included in the analysis.

Collocations denote the idea that certain semantic aspects of a node word is found in the surrounding words or expressions that frequently co-occur with the node word (McEnery and Hardie 2012). Given the focus on the semantic prosody of "Islam", only collocates with semantic content were analysed. According to Sinclair (1991), collocates that have semantic content are known as downward collocates, which in this study include three lexical categories, namely nouns, verbs and adjectives. Downward collocates contrast with upward collocates which are essentially grammatical and function words. In the current study, the downward collocates of "Islam" were analysed based on their frequency of occurrence in the MMN sub-corpus and the MEN sub-corpus. Following previous studies (Louw 1993; 2000; Sinclair 1991; 1998; Stubbs 1995a; 1995b; 1996) the downward collocates were then sorted and analysed for common patterns and themes.

The semantic prosody of "Islam" based on the analysis of the downward collocates was categorised as positive, negative, or neutral (Partington 2004). 
However, this may not be sufficient because despite the significance of collocates in analysing semantic prosody, linguists such as Hunston $(2007,256)$ have argued that "it may be that ascribing semantic prosody to a word is oversimplistic" and that a single word cannot be used as a descriptive label. To address this concern, in the current study, the collocates of "Islam" were also analysed based on their occurrence in context. To this end, the phraseology of the collocates was analysed by employing the Keyword in Context (KWIC) method, i.e. concordance lines. The outcome of the phraseological analysis is also used in discussing the cultural connotations of "Islam" that emerged in the data.

\section{Results and Analysis}

In the Malay (MMN) sub-corpus, "Islam" occurs 4,822 times. As pointed out earlier, "Islam" can function as both a noun and adjective in Malay but only as noun in English. So to ensure that the data is not skewed, the word "Islamic", which is the adjectival form of "Islam" in English was also analysed. The analysis shows that "Islam" and "Islamic" occur 5,078 times (1,099 for "Islam" and 3,979 for "Islamic") in the English (MEN) sub-corpus. In total therefore the words "Islam" and "Islamic" occur 9,900 times in the whole corpus. These frequencies essentially determined the number of collocates that were examined for the semantic prosody analysis. Collocates, in the context of the present study, are commonly recurring words with the node, i.e. "Islam" as a noun and an adjective in the MMN sub-corpus and the node "Islam/Islamic" in the MEN subcorpus. Given the size of the corpus, the minimum number of occurrence (frequency of collocates) set for the analysis of "Islam" is three. And as explained earlier, only downward collocates, namely verbs, adjectives and nouns that cooccur with "Islam/Islamic" were analysed. Therefore only verbs, adjectives and nouns that occur at least three times in the corpus are considered for analysis.

Table 2 below presents the data on the downward collocates of "Islam" and "Islamic" sorted by their lexical categories in the MEN sub-corpus. In total, 278 collocates were identified.

Table 2. Collocates of "Islam"/"Islamic" according to lexical category in the MEN subcorpus

\begin{tabular}{cc}
\hline Number of collocates & Lexical categories \\
\hline 195 & Nouns \\
38 & Verbs \\
45 & Adjectives \\
278 & Total number of collocates \\
\hline
\end{tabular}


Evidently, the most frequent lexical category that co-occurs with the keywords "Islam" and "Islamic" in the MEN sub-corpus is noun. The top ten nouns with the highest frequencies are "state", "finance", "development", "Maybank", "banking", "bank", "law", "funds", "world" and "international". There are also a considerable number of Malay nouns that collocate with "Islam", which include universiti (university), balai (centre), wilayah (federal territory), tadika (kindergarten) and pusat (centre). These Malay words are commonly found in names of Islamic institutions, organisations, or localities such as Pusat Asuhan Tadika Islam AlFahmi, Pusat Islam Melaka, Universiti Islam Antarabangsa Malaysia and Majlis Agama Islam Wilayah Persekutuan.

Another significant noun collocate that frequently co-occurs with "Islam" in the MEN sub-corpus is the word "Malays". The concordance lines show that the two words are often associated. The following examples demonstrate how the two words co-occur in the data:

1. "the interest of Malays, Islam and the nation",

2. "the rights of Malays, Islam and the monarchy",

3. "championing Islam, Malays" and

4. "future of the Malays, Islam and the royal institution".

The above findings suggest that in the MEN sub-corpus, many of the collocates of "Islam" are Malay nouns. As well, the noun "Malays" is also its common collocate.

As shown in Table 2, the second most frequent lexical category that collocates with "Islam" in the MEN sub-corpus is verb. Verb collocates with the highest frequencies are "join", "said", "called", "suspected", "support" and "told". These are followed by "insulting", "leading", "implement" and "based". These collocates suggest several recurring themes. Firstly, there are initiatives taken on "Islam" with verbs such as "support", "uphold", "spread", "developing" and "defend". The second theme suggests that Islam is in a kind of conflict. This is portrayed by verbs such as "suspected", "insulting", "fighting" and "contravened".

There are five verb collocates that suggest a neutral prosody of "Islam", namely "said", "told", "implement", "represent" and "entitled". This is supported by the analysis of the concordance lines of these verbs which show that they have neutral prosody. In some cases of "represent" where it is negated with the negative expression "not", one may argue that this has negative nuances. However, the concordance lines for the collocating verb "represent" from the 
MEN corpus suggest that the verb is used to negate something that is negative, such as the following examples:

1. "which did not represent Islam",

2. "less than animals, they don't represent Islam" and

3. "It is clear that Islamic State (IS) does not represent Islam".

The lexical category with the least number of co-occurrences with "Islam" is adjective. The adjectives that collocate with "Islam" frequently are "radical", "true", "moderate", "authentic", "antarabangsa" (Malay for international) and "liberal". Of all the adjectives, only one seems to be negative, namely "radical". Other collocates such as "true", "moderate", "authentic", "antarabangsa" and "liberal" have positive connotations.

The results of the collocational analysis of "Islam" in the MMN sub-corpus are presented in Table 3 below. In total, 228 collocates were identified.

Table 3. Collocates of "Islam" according to lexical category in the MMN sub-corpus

\begin{tabular}{cc}
\hline Number of collocates & Lexical categories \\
\hline 155 & Nouns \\
44 & Verbs \\
29 & Adjectives \\
228 & Total number of collocates \\
\hline
\end{tabular}

As with the MEN sub-corpus, the lexical category which co-occurs most frequently with "Islam" in the MMN sub-corpus is noun. Ten noun collocates with the highest frequencies are negara (country), umat (people of), agama (religion), perkuburan (cemetery), orang (people), "bank", kemajuan (development), negeri (state), universiti (university) and perbankan (banking). While the collocate negara essentially means "country", it is necessary to note here that in the corpus, negara co-occurs very frequently with "Islam" as Negara Islam which does not mean "Islamic country" but "Islamic State" (i.e. IS). This occurs 540 times out of 550. In Malay, the word for "state" is negeri but as evident from the MMN corpus, negara is used mostly as "state" which reflects the current global focus on the Islamic State (IS) group and the issues surrounding them.

There is also a significant number of collocating nouns which are Arabic words that have been borrowed and naturalised in the Malay language. These nouns are umat (people, especially Muslims), syiar (greatness), masjid (mosque), nur (light), muallaf (new Muslim convert), khalifah (caliph), syariah (law), raudhatul 
(paradise), jenazah (corpse/remains) and jihad. Words such as umat, syiar, muallaf and syariah are often associated with specific Islamic matters. Syiar frequently collocates immediately before "Islam" in the Malay corpus, such as syiar Islam and the verbs that commonly occur before the noun phrase are tegakkan and menegakkan (uphold), mengembangkan (develop or spread), perkembangan (development) and meninggikan (raise). The word muallaf in Arabic literally means "new relative". When naturalised in the Malay language, it is used to refer to new Muslim converts. Syariah, which means "law" in Arabic, frequently co-occurs with words such as mahkamah (court), peguam (attorney), undang-undang (law), enakmen (enactment) and kanun jenayah (penal code).

The lexical category with the second highest number of collocates is the verb. The 10 most frequently occurring verb collocates of "Islam" are katanya (he/she says/said), memeluk/peluk (convert), kata (says/said), menghina (insult/degrade), menunaikan (fulfill), menjadi (become/turn into), berteraskan (based on) and bersatu (unite). Verb collocates such as memperjuangkan (champion), mendalami (go indepth), menyebarkan (spread), mengikut (follow/conform), menghayati (experience/observe), menegakkan (uphold) and melindungi (protect) refer to actions that express effort in understanding, upholding and protecting Islam. Besides this theme, other verb collocates of "Islam" that are generated such as berteraskan (based on), berlandaskan (based on), dituntut (stipulated) and disaran (recommended) suggest that Islam acts as a guide for the local society and their way of life.

While the above collocates suggest a positive prosody of "Islam", there are verb collocates in the corpus that suggest that Islam is being victimised and misrepresented. The verbs include menghina (insult/degrade), mencerminkan (reflect), mengaitkan (associate), hina (insult) and meletakkan (place). Although some of these words seem to be neutral, upon further investigation, the verbs mencerminkan, mengaitkan, meletakkan occur in negative contexts. The sample concordance lines for the three verbs are as follows:

1. mencerminkan (reflect):

a) ideologi kumpulan IS tidak mencerminkan Islam yang sebenarnya (the ideology of the Islamic State group does not reflect true Islam)

b) pertubuhan militan itu tidak mencerminkan Islam dan mengancam dunia

(the militant group does not reflect Islam and is a threat to the world)

c) ia langsung tidak mencerminkan Islam (it does not reflect Islam at all) 
2. mengaitkan (associate):

a) ada pihak sentiasa cuba mengaitkan Islam dengan keganasan (there are parties that try to associate Islam with violence)

b) perbuatan yang sering mengaitkan Islam dengan keganasan (the action often associates Islam with violence)

c) persepsi Barat yang kerap mengaitkan Islam dengan keganasan (Western perception that frequently associates Islam with violence)

3. meletakkan (place):

a) mendorong pihak tertentu memburukkan atau meletakkan Islam dalam persepsi negatif (encourages certain parties to demean or place Islam in a negative light)

b) telah meletakkan Islam, dan bangsa Melayu dalam keadaan serba salah

(has placed Islam and the Malays in a predicament)

In the case of the verb mencerminkan, its occurrence with tidak (not) essentially negates the negative association being made with Islam. Mengaitkan (associate) commonly occurs with keganasan (violence) and meletakkan (place) collocates with words that suggest that Islam is put in a negative light by certain parties. These collocates, therefore, indicate that Islam is being misrepresented by certain parties.

The lexical category that collocates the least with "Islam" in the MMN subcorpus is adjective. The most frequently co-occurring adjectives are kewangan (financial), beragama (of a certain religion), antarabangsa (international), "mega", "global", sedunia (worldwide), berpakaian (clothed), terbesar (biggest), selesai (complete) and sederhana (moderate). There are not many distinguishable patterns or themes observable from these adjectives. However, one theme that seems to emerge is the enormity of Islam. This theme is portrayed in the words "mega", terbesar (biggest), antarabangsa (international), "global" and sedunia (worldwide).

\section{Cultural Connotations of "Islam" in Malaysia English and Malay}

From the data collected, it is found that there are 4,822 hits for "Islam" in the MMN sub-corpus and 5,078 hits for "Islam" and "Islamic" in the MEN subcorpus. As stated at the outset of the study, the reason for taking both words into account in the MEN sub-corpus is because of the nature of the word "Islam" in the two languages. In the Malay language, the word "Islam" functions both as a noun and adjective, whereas in the English language it only functions as a noun. Therefore, the adjective "Islamic" was also taken into account for a more 
balanced representation of "Islam" in the English sub-corpus. The study found that in the MEN sub-corpus, "Islamic" occurs more frequently than the noun "Islam". It can be deduced that "Islam" in the English corpus occurs more often as an attribute to describe something, such as "Islamic finance", "Islamic party", "Islamic State" (examples provided are extracted from the corpus used in this study), rather than as a subject.

As discussed earlier, there are several themes that emerged from the collocational analysis of the downward collocates of "Islam". Firstly, in the whole corpus (MEN and MMN), the nouns "Malay" and Melayu are found to be common collocates of the word under study. This finding strongly supports the inherent connection between the Malays, Malay language and Islam in Malaysia. The analysis also shows that the institutionalisation of Islam in the country is evident from the numerous names of organisations, banks and universities such as Majlis Agama Islam Wilayah Persekutuan, Bank Islam and Universiti Islam Antarabangsa Malaysia that emerged in the corpus.

With regard to verbs that collocate with "Islam" in the two sub-corpora, the analysis shows that Islam is something to strive for and that as a religion, Islam functions more than just a belief. It also importantly acts as a moral and living guide for the local Muslim community, especially the Malays. On the other hand, there are also collocating verbs which carry negative connotations as they refer to actions against Islam. However these collocating verbs are not associated with Islam and Muslims in Malaysia as they are generally connected or addressed towards foreign Muslims. This finding accord the results of the studies by d'Haenens and Bink (2006) and Dahinden et al. (2011) that found that the negative representations of Islam in their local media are directed towards foreign Muslims rather than local Muslims.

Where adjectives are concerned, the analysis of adjectives such as "moderate" and sederhana that collocate with the word "Islam" suggests the inclination towards "moderate Islam" in the Malaysian context, while the adjectives "true", "authentic" and sebenar allude to the truth and authenticity of Islam as a religion.

\section{Conclusion}

While the results show that there are a number of similar themes that emerged from the collocations in the English and Malay sub-corpora, there are also certain themes that are unique to each of the languages. In the Malay language, "Islam" is found to be embedded in the language and culture of the Malay community especially. This is evident from the existence of various Arabic words related to Islam in the Malay language, such as syariah and masjid. In the English sub- 
corpora on the other hand, it is found that aside from being institutionalised in universities, schools and organisations, it is also frequently used in financial establishments. Collocations such as "bank"/"banking", "finance", "funds" and names of financial establishments in Malaysia such as "Maybank", "CIMB" and "RHB" occur significantly higher in the English corpus than in the Malay corpus. This finding brings to mind the notion of moderate Islamism. According to Miichi $(2006,127)$, "Islamism is a political discourse similar to other political discourses such as socialism and liberalism... Islamism has inherited some characteristics of modernism that aim to return to the Qur'an and Hadith and...Islamism largely employs modern technology and institutions".

From the above, it can be concluded that Islam, being inherent in the Malay language and culture is linked to the people who profess Islam, religion and religious practices, cultural matters, law and way of life. This inevitably causes Islam to inherit a generally positive cultural connotation which in turn discourages associations with pejorative terms that can give rise to negative prosody. In the English language in Malaysia, it is perhaps not wrong to deduce that the association of "Islam" and "Islamic" with academic institutions, social bodies as well as finance and banking also conjures up a cultural connotation that is generally positive. While negative references are also available in the data of the study, these are not significant. The generally positive connotations of Islam that emerged in the English corpus of the study contrast with past studies on Islam in other contexts, particularly in Western Muslim-minority localities, where it has been found to be portrayed negatively. This importantly shows that the pejoration or amelioration of an expression is not rooted in a language, but very much influenced by context and use. The findings also strongly support the notion that English is an International Language (Sharifian 2009; 2013) as the meanings and cultural connotations of a word, such as "Islam" are dependent on the cultural background of the speakers of the language.

The findings of the current study essentially reflect the reality of Islam in contemporary Malaysia based on one genre of texts, i.e. newspapers. Nonetheless, the findings shed important light on the cultural connotations of Islam in a multi-ethnic and multi-religious country where it is pervasive at various levels of society and sectors of the country. Its history and long-standing connection to a major part of the society, both Muslims and non-Muslims is the main reason for its familiarity. The Islamic discourse that emerges from the names of educational and financial institutions, social organisations and spaces, living concepts and so on pervades the psyche of the local community. Thus, the general local discourse which projects a "moderate" Islam is unlike the global discourse which seems to project an undesirable image of Islam. 
In conclusion, the findings essentially suggest that the cultural connotations of the word "Islam" in Malaysia are aligned with the religion's social value and status in the country. And importantly, despite the onslaught of the negative representation of Islam at the global level, the cultural connotations of the word "Islam" that emerged in the current study suggest that the local is not always responsive to the global.

\section{Note}

1. This phenomenon has its roots in the colonial and postcolonial history of Malaysia. Thus although the Malay language is widely used by Malaysians and an important lingua franca (Asmah 1992), Malaysians do widely practise other languages such as English, Hokkien, Cantonese, Tamil, Telugu, Iban, Bajau, etc., depending on their personal ethnic, socio-economic and educational backgrounds.

\section{Bibliography}

Ahmad Fauzi Abdul Hamid and Muhamad Takiyuddin Ismail. 2014. Islamist conservatism and the demise of Islam Hadhari Malaysia. Islam and ChristianMuslim relation 25(2): 159-180, https://doi.org/10.1080/09596410.2014.880549.

Aini Maznina A. Manaf and Nerawi Sedu. 2015. Framing Islam-related issues during GE13: An analysis of Malaysian mainstream newspapers. Intellectual Discourse 23(1): 29-52.

Anthony, L. 2015. AntConc 3.4.3m [Computer software]. Waseda, Japan: Waseda University.

Asmah Haji Omar. 1992. The linguistic scenery in Malaysia. Kuala Lumpur: Dewan Bahasa and Pustaka.

Baker, P. 2012. Acceptable bias? Using corpus linguistics methods with critical discourse analysis. Critical Discourse Studies 9(3): 247-256, https://doi.org/10.1080/ 17405904.2012 .688297$.

. 2010. Representations of Islam in British broadsheet and tabloid newspapers 1999-2005. Journal of Language and Politics 9(2): 310-338, https://doi.org/10.1075/jlp.9.2.07bak.

Baker, P., Gabrielatos, C. and McEnery, T. 2012. Sketching Muslims: A corpus driven analysis of representations around the word "Muslim" in the British press 19982009. Applied Linguistics 34(3): 255-278, https://doi.org/10.1093/applin/ams048.

Begagić, M. 2013. Semantic preference and semantic prosody of the collocation make sense. Jezikoslivlje 14(2-3): 403-416.

d'Haenens, L. and Bink, S. 2006. Islam in the Dutch press: With special attention to the Algemeen Dagblad. Media, Culture and Society 29(1):135-149, https://doi.org/10.1177/0163443706072002.

Dahinden, U., Koch, C., Wyss, V. and Keel, G. 2011. Representation of Islam and Christianity in the Swiss Media. Journal of Empirical Theology 24: 197-208, https://doi.org/10.1163/157092511X603983. 
Gabrielatos, C. and Baker, P. 2008. Fleeing, sneaking, flooding: A corpus analysis of discursive constructions of refugees and asylum seekers in the UK press, 19962005. Journal of English Linguistics 36(1): 5-38, https://doi.org/10.1177/ 0075424207311247.

Hajar Abdul Rahim. 2005. Impak konotasi budaya terhadap leksis: satu kajian semantik berasaskan korpus ke atas perkataan "perempuan" dan "wanita" (The impact of cultural connotations on lexis: A corpus-based semantic analysis of perempuan and wanita). Jurnal Bahasa 5(1): 83-111.

Hajar Abdul Rahim and Shakila Abdul Manan. 2014. Postcolonial Malaysian English: Realities and prospects. In English in Malaysia: Postcolonial and beyond, eds. Hajar Abdul Rahim and Shakila Abdul Manan, 9-33. Amsterdam: Peter Lang.

Hishamudin Isam and Norsimah Mat Awal. 2012. Nilai setia dari perspektif prosodi semantik: Analisis berbantu data korpus. GEMA Online Journal of Language Studies 12(2): 359-374.

Hunston, S. 2007. Semantic prosody revisited. International Journal of Corpus Linguistics 12(2): 249-268, https://doi.org/10.1075/ijcl.12.2.09hun.

Jackson, L. 2010. Images of Islam in US media and their educational implications. Educational Studies 46(1): 3-24, https://doi.org/10.1080/00131940903480217.

Johnson, T. M., Zurlo, G. A., Hickman, A. W. and Crossing, P. F. 2015. Christianity 2015: Religious diversity and personal contact. International Bulletin of Missionary Research 39(1): 28-29.

Kabir, N. 2007. Representation of Islam and Muslims in the Australian media, 20012005. Journal of Muslim Minority Affairs 26(3): 313-328, https://doi.org/ 10.1080/13602000601141281.

Kisaichi, M. 2006. The Burhami order and Islamic resurgence in modern Egypt. In Popular movements and democratization in the Islamic world, ed. Kisaichi, M., 57-77. London: Routledge.

Kubota, R. 2013. "Language is only a tool": Japanese expatriates working in China and implications for language teaching. Multilingual Education 3(4): 1-20, https://doi.org/10.1186/2191-5059-3-4.

Laird, L. D., de Marrais, J. and Barnes, L. L. 2007. Portraying Islam and Muslims in MEDLINE: A content analysis. Social Science and Medicine 65: 2425-2439, https://doi.org/10.1016/j.socscimed.2007.07.029.

Louw, B. 2000. A contextual prosodic theory: Bringing semantic prosodies to life. In Words in context: A tribute to John Sinclair on his retirement, eds. Heffer, C. and Sauntson, H., 48-94. Amsterdam/Philadelphia: John Benjamins.

. 1993. Irony in the text or insincerity in the writer? The diagnostic potential of semantic prosodies. In Text and technology: In honour of John Sinclair, eds. Baker, M., Francis, G. and Tognini-Bonelli, E., 157-176. Amsterdam /Philadelphia: John Benjamins, https://doi.org/10.1075/z.64.11lou.

Mahboob, A. 2009. English as an Islamic language: A case study of Pakistani English. World Englishes 28(2): 175-189, https://doi.org/10.1111/j.1467-971X.2009. 01583.x.

Malcolm, D., Bairner, A. and Curry, G. 2010. "Woolmergate": Cricket and the representation of Islam and Muslims in the British Press. Journal of Sports and Social Issues 34(2): 215-235, https://doi.org/10.1177/0193723510367768. 
Martin, P. and Phelan, S. 2002. Representing Islam in the wake of September 11: A comparison of US television and CNN Online message board discourses. Prometheus 20(3): 263-269, https://doi.org/10.1080/08109020210141371.

Maznah Mohamad. 2011. Like a shady tree swept by the windstorm: Malays in dissent. In Melayu: The politics, poetics and paradoxes of Malayness, eds. Maznah Mohamad and Syed Muhd Khairudin Aljuneid, 34-67. Singapore: NUS Press.

McEnery, T. and Hardie, A. (2012) Corpus linguistics: Method, theory and practice. Cambridge: Cambridge University Press.

McKay, S. L. 2013. Globalization, localization and language attitudes: The case of "foreign workers" in Singapore. Multilingual Education 3(3): 1-12, https://doi.org/10.1186/2191-5059-3-3.

Miichi, K. 2006. Penetration of "moderate" Islamism in contemporary Indonesia. In Popular movements and democratization in the Islamic world, ed. Kisaichi, M., 126-142. London: Routledge.

Mohd Azizuddin Mohd Sani, Norhafezah Yusof, Azahar Kassim and Rusdi Omar. 2009. Malaysia in transition: A comparative analysis of Asian values, Islam Hadhari and 1Malaysia. Journal of Politics and Law 2(3): 110-118.

Neo, J. L. 2014. What's in a name? Malaysia's "Allah" controversy and the judicial intertwining of Islam with ethnic identity. I-CON 12(3): 751-768, https://doi.org/10.1093/icon/mou050.

Norshahril Saat. 2011. Islamising Malayness: Ulama discourse and authority in contemporary Malaysia. Contemporary Islam 6: 135-153, https://doi.org/ 10.1007/s11562-011-0172-9.

Partington, A. 2004. "Utterly content in each other's company": Semantic prosody and semantic preference. International Journal of Corpus Linguistics 9(1): 131-156, https://doi.org/10.1075/ijcl.9.1.07par.

Payne, R. J. and Nassar, J. R. 2003. Politics and culture in the developing world. New York: Pearson Education Inc.

Rundell, M. 2000. Slumped in front of the telly. In Humanising language teaching 1. Retrieved from http://www.hltmag.co.uk/jan00/idea.htm.

Sankar, L. V. 2013. Malaysia editorials on the Allah issue: A critical discourse study. Critical Inquiry in Language Studies 10(1): 31-61, https://doi.org/10.1080/ 15427587.2013.753842.

Sapir, E. 1921. Language: An introduction to the study of speech. New York: Harcourt, Brace and Co.

Sharifian, F. 2013. Globalisation and developing metacultural competence in learning English as an international language. Multilingual Education 3(7): 1-11, https://doi.org/10.1186/2191-5059-3-7.

. 2009. Cultural conceptualizations in English as an international language. In English as an international language: Perspectives and pedagogical issues, ed. Sharifian, F., 242-253. Bristol, United Kingdom: Multilingual Matters.

Sinclair, J. 1998. The lexical item. In Contrastive lexical semantics, ed. Weigand, E., 124. Amsterdam/Philadelphia: John Benjamins, https://doi.org/10.1075/cilt. 171.02sin. 1987. Looking up. London: Collins COBUILD.

Sinclair, J. M. 1991. Corpus, concordance and collocation. Oxford: Oxford University Press. 
Stubbs, M. 2009. The search for units of meaning: Sinclair on empirical semantics. Applied Linguistics 30(1): 115-137, https://doi.org/10.1093/applin/amn052. 1996. Text and corpus linguistics. Oxford: Blackwell.

1995a. Collocations and cultural connotations of common words. Linguistics and Education 7: 379-390, https://doi.org/10.1016/0898-5898(95)90011-X.

1995b. Collocations and semantic profiles: On the cause of the trouble with quantitative studies. Functions of Languages 2(1): 23-55, https://doi.org/ 10.1075/fol.2.1.03stu.

Xiao, R. and McEnery, T. 2006. Collocation, semantic prosody and near synonymy: A cross-linguistic perspective. Applied Linguistics 27(1): 103-129, https://doi.org/ 10.1093/applin/ami045.

Yegar, M. 1979. Islam and Islamic institutions in British Malaya: Policies and implements. Jerusalem: The Magnes Press. 